\title{
The CCL20-CCR6 Axis in Cancer Progression
}

\author{
Suguru Kadomoto ${ }^{\circledR}$, Kouji Izumi * ${ }^{\mathbb{1}}$ and Atsushi Mizokami \\ Department of Integrative Cancer Therapy and Urology, Kanazawa University Graduate School of Medical \\ Science, 13-1 Takara-machi, Kanazawa 920-8641, Ishikawa, Japan; 32f3k8@bma.biglobe.ne.jp (S.K.); \\ mizokami@staff.kanazawa-u.ac.jp (A.M.) \\ * Correspondence: azuizu2003@yahoo.co.jp; Tel.: +81-76-265-2393; Fax: +81-76-234-4263
}

Received: 16 June 2020; Accepted: 16 July 2020; Published: 22 July 2020

\begin{abstract}
Chemokines, which are basic proteins that exert their effects via $G$ protein-coupled receptors and a subset of the cytokine family, are mediators deeply involved in leukocyte migration during an inflammatory reaction. Chemokine (C-C motif) ligand 20 (CCL20), also known as macrophage inflammatory protein (MIP)-3 $\alpha$, liver activation regulated chemokine (LARC), and Exodus-1, is a small protein that is physiologically expressed in the liver, colon, and skin, is involved in tissue inflammation and homeostasis, and has a specific receptor C-C chemokine receptor 6 (CCR6). The CCL20-CCR6 axis has long been known to be involved in inflammatory and infectious diseases, such as rheumatoid arthritis and human immunodeficiency virus infections. Recently, however, reports have shown that the CCL20-CCR6 axis is associated with several cancers, including hepatocellular carcinoma, colorectal cancer, breast cancer, pancreatic cancer, cervical cancer, and kidney cancer. The CCL20-CCR6 axis promotes cancer progression directly by enhancing migration and proliferation of cancer cells and indirectly by remodeling the tumor microenvironment through immune cell control. The present article reviewed the role of the CCL20-CCR6 axis in cancer progression and its potential as a therapeutic target.
\end{abstract}

Keywords: chemokines; CCL20-CCR6 axis; cancer progression

\section{Introduction}

Cytokines are proteins produced by various cells, including immunocompetent cells that exert limited physiological activity. Most cytokines are soluble extracellular proteins with small molecular weights $(5-20 \mathrm{kDa})$ that act by binding to specific receptors on target cells. Cytokines not only play important roles in the immune system, such as regulating the balance between humoral and cellular immunity, but also act on a wide range of cells, such as endothelial cells and fibroblasts. Cytokines sometimes damage tumor cells by inducing leukocyte antitumor cytotoxic activity. However, cytokines have been found to be significantly upregulated in many cancers, promoting cancer growth and progression within the tumor microenvironment (TME) [1,2]. Cytokines are classified into interleukins (IL), interferons (IFN), tumor necrosis factors (TNF), growth factors, hematopoietic factors, and chemokines. Accordingly, chemokines are proteins of relatively low molecular weight $(8-14 \mathrm{kDa})$ and are classified into C-C motif (CC), C-X-C motif (CXC), C-motif (C), and CXC3 chemokines according to structural differences [3]. To date, around 50 types of chemokines have been identified $[4,5]$. The primary role of chemokines is to participate in leukocyte development, differentiation, and migration. However, chemokines are also involved in angiogenesis, wound healing, inflammatory diseases, and progression of malignancies, such as adult T-cell leukemia and many solid tumors [6-10]. Although chemokines exert antitumor effects, including induction of cytotoxic $\mathrm{T}$ cells into tumor tissues, they have also been known to assist cells that suppress tumor immunity, such as tumor-associated macrophages (TAM), myeloid-derived immune suppressor cells (MDSC), 
and regulatory T cells (Treg) [9-11]. Furthermore, chemokines can directly activate cancer cells via their corresponding receptors. However, the mechanisms of chemokine-related cancer activation have still remained mostly unclear. The present article highlighted the unique role of chemokine (C-C motif) ligand 20 (CCL20), which belongs to the CC chemokine family, and its specific receptor C-C chemokine receptor 6 (CCR6) in cancer progression.

\section{Basic Information Regarding CCL20 and CCR6}

CCL20, which is known by several names, including macrophage inflammatory protein (MIP)-3 $\alpha$, Exodus-1, and liver and activation-regulated chemokine (LARC) [12,13], is expressed in various human tissues and immune cells and has been observed mainly in lymph nodes, lungs, and liver [12,14,15]. At the cellular level, endothelial cells, neutrophils, T helper (Th) 17 cells (Th17), B cells, natural killer cells, dendritic cells (DC), and macrophages have been reported to secrete CCL20 [16-18].

In 1997, Baba et al. reported that the specific receptor for CCL20 was CCR6 [19], a 7-transmembrane domain $\mathrm{G}$ protein-coupled receptor strongly expressed in the intestinal mucosa, lung mucosa, and lymph nodes, and highly in epithelial tumors [20-24]. At the cellular level, CCR6 is predominantly expressed on immune cells, such as Th17, Treg, CD8+ T cells, and B cells [25-27].

\section{Role of the CCL20-CCR6 Axis in Cancer Progression and Tumor Microenvironment}

Tumor growth can be regulated by not only internal tumor cell signals but also external factors. Studies have shown that tumor cells emit various signals to reconstruct a favorable environment for themselves. Generally, although normal immune cells attack and suppress cancer cells, some immune cells that infiltrate into cancer tissue lose their antitumor function and play a role in promoting tumor progression [28,29]. Therefore, a proper understanding of the TME and selection of therapeutic targets is important. However, the TME, which contains tumor cells, fibroblasts, immune cells (e.g., T cells), pericytes, endothelial cells, mesenchymal stem cells, adipocytes, red blood cells, and many other components, is considerably complex [30,31]. Furthermore, tumors develop in a different physiological environment. For instance, liver cancer develops in the presence of inflammation and fibrosis [32], which may not be that impactful in prostate and breast cancers. Although the cause of renal cell carcinoma (RCC) remains unknown in most cases, the RCC TME among patients undergoing dialysis and those with Von Hippel-Lindau (VHL) gene abnormality has been considered to differ significantly. Moreover, the TME can even differ among the same tumor types depending on the disease stage, thereby changing the expected target for effective treatment [33].

Signaling substances, such as cytokines released from tumor cells, stromal cells, and immune cells, are extremely important in the TME [34]. Accordingly, cytokines secreted by cancer cells affect a wide range of processes, such as autocrine signaling, paracrine signaling, and the circulatory system, and create a favorable environment for cancer cells by affecting various receptors. The main functions of chemokines include recruitment and signaling of immune cells, which cancer cells use to their advantage [35]. Although CCL20 exhibits antibacterial activity and may cause autoimmune diseases, such as rheumatoid arthritis, psoriasis, and inflammatory bowel disease, the evidence clearly suggests that the CCL20-CCR6 axis within the TME is strongly associated with cancer, with studies having reported several factors affected by the CCL20-CCR6 axis (Table 1). 
Table 1. Tumor promoting effects of CCL20 within the tumor microenvironment.

\begin{tabular}{|c|c|c|c|c|}
\hline Cancer Types & Specimens & Factors & Description Contents & References \\
\hline $\mathrm{HCC}$ & Tissue & - & $\begin{array}{l}\text { High expression of CCL20 in tumor tissues exacerbates } \\
\text { recurrence rate and survival among patients with HCC. }\end{array}$ & [36] \\
\hline $\mathrm{HCC}$ & Tissue & BDTT & $\begin{array}{l}\text { CCL20 is highly expressed in BDTT and is a poor factor in } \\
\text { HCC prognosis. }\end{array}$ & [37] \\
\hline $\mathrm{HCC}$ & $\begin{array}{l}\text { Blood } \\
\text { Tissue } \\
\text { Cell lines } \\
\text { Mouse model }\end{array}$ & B cells & $\begin{array}{l}\text { Tumor cell-derived CCL20 interacts with CCR6-highly } \\
\text { expressed CD19+CD5+ B cells to promote HCC progression } \\
\text { through enhanced angiogenesis. }\end{array}$ & [38] \\
\hline $\mathrm{HCC}$ & $\begin{array}{l}\text { Blood } \\
\text { Tissue }\end{array}$ & STAT3 & $\begin{array}{l}\text { Tumor cells transfected with STAT3 siRNA show significantly } \\
\text { lower CCL20 expression than control tumor cells. }\end{array}$ & [39] \\
\hline Breast cancer & $\begin{array}{l}\text { Tissue } \\
\text { Cell lines } \\
\text { Mouse model }\end{array}$ & HuR & $\begin{array}{l}\text { HuR enhances the invasion of cancer cells through CCL20 and } \\
\text { GM-CSF. }\end{array}$ & [40] \\
\hline Breast cancer & $\begin{array}{l}\text { Blood } \\
\text { Tissue } \\
\text { Cell lines } \\
\text { Mouse model }\end{array}$ & NF- $k B$ & $\begin{array}{l}\text { CCL20 expression in TNBC induces taxane resistance via the } \\
\text { NF- } \mathrm{KB} \text { pathway. }\end{array}$ & [41] \\
\hline CRC & $\begin{array}{l}\text { Blood } \\
\text { Tissue }\end{array}$ & IL17A & $\begin{array}{l}\text { Serum CCL20 and IL17A levels are identified as independent } \\
\text { prognostic markers for CRC. }\end{array}$ & [42] \\
\hline CRC & $\begin{array}{l}\text { Blood } \\
\text { Tissue } \\
\text { Cell lines } \\
\text { Mouse model }\end{array}$ & $\begin{array}{l}\text { Treg } \\
\text { NF-kB }\end{array}$ & $\begin{array}{l}\text { CRC cell-secreted CCL20 can recruit Treg to promote } \\
\text { chemoresistance via FOXO1/CEBPB/NF-KB signaling. }\end{array}$ & [43] \\
\hline $\begin{array}{l}\text { Pancreatic } \\
\text { cancer }\end{array}$ & $\begin{array}{l}\text { Blood } \\
\text { Cell lines }\end{array}$ & NF- $к B$ & $\begin{array}{l}\text { Pancreatic cancer cells also acquire TRAIL resistance by } \\
\text { recruiting immune cells with CCL20. }\end{array}$ & {$[44]$} \\
\hline $\begin{array}{l}\text { Pancreatic } \\
\text { cancer }\end{array}$ & $\begin{array}{c}\text { Blood } \\
\text { Cell lines } \\
\text { Mouse model }\end{array}$ & $\begin{array}{l}\text { TAM } \\
\text { AKT } \\
\text { ERK }\end{array}$ & $\begin{array}{l}\text { M2 macrophages secrete CCL20 and increase pancreatic } \\
\text { cancer cell invasiveness. }\end{array}$ & [45] \\
\hline $\begin{array}{l}\text { Prostate } \\
\text { cancer }\end{array}$ & Tissue & - & $\begin{array}{l}\text { Strong CCR6 expression in prostate cancer tissue is a poor } \\
\text { prognostic factor. }\end{array}$ & [46] \\
\hline $\begin{array}{l}\text { Prostate } \\
\text { cancer }\end{array}$ & $\begin{array}{l}\text { Tissue } \\
\text { Cell lines } \\
\text { Mouse model }\end{array}$ & $\begin{array}{l}\text { CXCL12 } \\
\text { CXCR4 }\end{array}$ & $\begin{array}{l}\text { CXCL12 derived from cancer-associated fibroblasts acts on } \\
\text { CXCR4 of prostate cancer cells, and the prostate cancer cells } \\
\text { overexpress CCL20 and progress. }\end{array}$ & [47] \\
\hline Lung cancer & $\begin{array}{l}\text { Tissue } \\
\text { Cell lines } \\
\text { Mouse model }\end{array}$ & Nitrosaminoketone & $\begin{array}{l}\text { Nitrosaminoketone induces the production of CCL20 and } \\
\text { promotes the proliferation and migration of lung cancer cells. } \\
\text { High expression of CCL20 in lung cancer tissues is a poor } \\
\text { prognostic factor. }\end{array}$ & [48] \\
\hline Lung cancer & $\begin{array}{l}\text { Tissue } \\
\text { Cell lines } \\
\text { Mouse model }\end{array}$ & $\begin{array}{l}\operatorname{lncRNA-u} 50535 \\
\text { ERK }\end{array}$ & $\begin{array}{l}\text { lncRNA-u5053 upregulates CCL20 expression in lung cancer } \\
\text { cells, and lung cancer cells enhance proliferation and } \\
\text { migration via the CCL20/CCR6/ERK axis. }\end{array}$ & [49] \\
\hline Lung cancer & $\begin{array}{l}\text { Tissue } \\
\text { Cell lines }\end{array}$ & ERK & $\begin{array}{l}\text { CCL20 and CCR6 are highly expressed in recurrent lung } \\
\text { cancer tissue. Lung cancer cells activate the CCL20/CCR6/ERK } \\
\text { axis via autocrine or paracrine mechanisms to promote } \\
\text { proliferation and migration. }\end{array}$ & {$[50]$} \\
\hline Cervical cancer & $\begin{array}{l}\text { Tissue } \\
\text { Cell lines }\end{array}$ & Th17 & $\begin{array}{l}\text { Th17 cells are recruited into tumor tissues preferentially } \\
\text { through CCL20-CCR6 pathway. }\end{array}$ & [51] \\
\hline Cervical cancer & $\begin{array}{l}\text { Tissue } \\
\text { Cell lines }\end{array}$ & Th17 & $\begin{array}{l}\text { IL6 derived from cervical cancer cells stimulates cervical } \\
\text { fibroblasts and induces CCL20 secretion. }\end{array}$ & [52] \\
\hline Gastric cancer & Tissue & - & $\begin{array}{l}\text { The expression of CCR6 in gastric cancer cells is upregulated } \\
\text { as compared with that in normal tissues, and the high } \\
\text { expression of CCR6 is an independent poor prognostic factor. }\end{array}$ & [24] \\
\hline Gastric cancer & $\begin{array}{l}\text { Tissue } \\
\text { Cell lines }\end{array}$ & $\begin{array}{l}\text { CrkL } \\
\text { ERK }\end{array}$ & $\begin{array}{l}\text { Gastric cancer cells are stimulated by the } \\
\text { CCL20/CCR6-CrkL-ERK } 1 / 2 \text { axis to enhance invasion, and the } \\
\text { high expression of CCR } 6 \text { and CrkL in cancer tissues is an } \\
\text { independent poor prognostic factor. }\end{array}$ & [53] \\
\hline Ovarian cancer & $\begin{array}{l}\text { Tissue } \\
\text { Blood } \\
\text { Cell lines }\end{array}$ & $\begin{array}{l}\text { Macrophage } \\
\text { Cisplatin }\end{array}$ & $\begin{array}{l}\text { Macrophages stimulated by cisplatin produce CCL } 20 \text { and } \\
\text { enhance the migration of ovarian cancer cells. }\end{array}$ & [54] \\
\hline $\mathrm{RCC}$ & $\begin{array}{l}\text { Tissue } \\
\text { Cell lines }\end{array}$ & $\begin{array}{l}\text { TAM } \\
\text { AKT }\end{array}$ & $\begin{array}{l}\text { TAM enhances RCC cell migration through the } \\
\text { CCL20-CCR6 pathway. }\end{array}$ & [55] \\
\hline
\end{tabular}

HCC, hepatocellular carcinoma; BDTT, bile duct tumor thrombus; HuR, human antigen R; GM-CSF, granulocyte-macrophage colony-stimulating factor; TNBC, triple-negative breast cancer; STAT3, signal transduction and activator of transcription 3; CRC, colorectal cancer; Treg, regulatory T cells; FOXO1, forkhead box protein O1; CEBPB, CCAAT enhancer-binding protein beta; NF-KB, nuclear factor kappa B; IL17, interleukin 17; ERK, extracellular signal-regulated kinase; CXCL12, chemokine (C-X-C motif) ligand 12; CXCR, C-X-C chemokine receptor type 4 TRAIL, human tumor necrosis factor (TNF)-related apoptosis-inducing ligand; TAM, tumor-associated macrophages; Th17, T helper 17 cells; CrkL, CT10 regulator of kinase like protein. 


\subsection{Hepatocellular Carcinoma (HCC)}

HCC, the main type of primary liver cancer, is the third leading cause of cancer-related deaths worldwide [56]. The main risk factors for HCC include chronic hepatitis $B$, hepatitis $C$ virus infection, alcohol abuse, metabolic disorders, smoking, obesity, and diabetes. Partial hepatectomy has been the curative treatment option for patients with HCC who have an adequate liver function, although high recurrence rates have continued to be a concern [57,58]. The CCL20-CCR6 axis is also regarded as a key contributor to the progression of HCC [59]. Accordingly, Ding et al. found that tissue CCL20 expression was associated with tumor size, tumor number, vascular invasion, tumor differentiation, and tumor recurrence, and patients with high CCL20 expression had poorer recurrence-free survival and overall survival than those with low CCL20 expression [36]. Moreover, Yang et al. showed that bile duct tumor thrombosis and high CCL20 expression levels were poor prognostic factors for HCC [37]. Another study has revealed that CCL20 has been significantly upregulated in HCC tissues, while pretreatment serum CCL20 levels have been closely associated with patient survival [38]. The same study has found that CCL20 produced by HCC cells recruits CCR6+CD $5+B$ cells and induces angiogenesis to promote tumor growth and that blocking CCL20 suppressed angiogenesis. Overall, the highlighted studies suggest that the CCL20-CCR6 axis may be a novel target for HCC treatment.

\subsection{Breast Cancer}

Breast cancer, the most common cancer among women [60], can be classified into several subtypes according to the expression of estrogen receptor (ER), progesterone receptor (PR), human epidermal growth factor receptor 2 (HER2), and Ki-67. Among them, ER-, PR-, and HER2-breast cancers have been known as triple-negative breast cancer (TNBC) to have a poor prognosis. Recently, however, CCL20 has also been associated with poor breast cancer prognosis. Among patients with breast cancer, those with high CCL20 expression have significantly lower overall survival and metastasis-free survival. One study has shown that intraperitoneal administration of anti-CCL20 antibody has inhibited osteolytic breast cancer bone metastasis in a mouse model, and CCL20 has significantly enhanced cell invasion and secretion of matrix metalloproteinase (MMP) 2 and 9 in TNBC cell lines [40]. Chemotherapy resistance has been a major issue in the treatment of TNBC. CCL20 promotes self-renewal and maintenance of breast cancer stem cells and breast cancer stem-like cells by activating p65 nuclear factor kappa B (NF- $\mathrm{kB}$ ) via protein kinase $\mathrm{C}$ or p38 mitogen-activated protein kinase. Furthermore, CCL20-stimulated NF- $\mathrm{kB}$ activation increases multidrug resistance 1 expression and promotes taxane extracellular excretion. The aforementioned results suggest that CCL20 is an important target for chemoresistance in breast cancer [41].

\subsection{Colorectal Cancer (CRC)}

Early diagnosis of CRC, which is common among both men and women [60], is important for improving prognosis, with CCL20 being a candidate biomarker. Accordingly, studies have shown that patients with CRC have significantly higher serum CCL20 and interkeukin-17 A (IL17A) levels than healthy individuals, and that receiver operating characteristic curve analysis combining CCL20 and IL17A is effective in distinguishing patients with CRC from healthy individuals [42]. Recurrence and metastasis in CRC have been the main causes of death among patients, while chemoresistance has remained a major therapeutic challenge. One study has shown that CCL20 expression level in CRC cells has been significantly increased among cases resistant to FOLFOX regimen chemotherapy and has been closely associated with worse survival [43]. Furthermore, CRC cells secrete CCL20 and recruit Treg into tumor tissues, enhancing their chemoresistance [43]. Based on available evidence, CCL20 can be considered a useful diagnostic marker and treatment target for CRC. 


\subsection{Pancreatic Cancer}

Pancreatic cancer has one of the worst prognoses among carcinomas, with a 5-year survival rate of only $8 \%$. Although several cancers have had extended survival rates due to advancements in cancer treatment, little improvement has been made for pancreatic cancer, given its rapid progression without symptoms and strong resistance to chemotherapy $[60,61]$. Considering that majority of patients cannot undergo curative resection, drug therapy is important. The transcriptional pathway NF- $\mathrm{KB}$ is particularly important, given its involvement in apoptosis resistance. One study has shown that CCL20 is the strongest target gene in TNF-related apoptosis-inducing ligand (TRAIL) resistance through the NF-кB subunit RelA [44]. Pancreatic cancer cells acquire TRAIL resistance through not only autocrine CCL20 but also paracrine recruitment of immune cells [44]. Among the immune cells, TAM expressing M2-type macrophage markers have been shown to promote tumor progression and suppress cytotoxic T-cell responses. Moreover, IL4-stimulated M2-type macrophages strongly express CCL20 and promote epithelial-mesenchymal transition (EMT) and pancreatic cancer cell invasion. Another study has shown that the CCL20-CCR6 axis has also promoted pancreatic cancer growth and liver metastasis in vivo in a mouse model [45].

\subsection{Prostate Cancer}

Inflammatory cytokines and chemokines released by macrophages in the prostate cancer microenvironment may signal via the androgen receptor to influence tumor progression [62]. It has been demonstrated that the interaction of infiltrating macrophages and prostate cancer cells mediates the hormone resistance of prostate cancer cells [63]. Expression levels of CCR6 in prostate cancer are associated with clinical and pathologic features of more advanced and aggressive prostate cancer status, such as local tumor volume, Gleason score, and lymph node metastasis [46]. One study has shown that the chemokine receptor CXCR4 stimulates the production of the chemokine CCL20 and that CCL20 stimulates the proliferation and adhesion to collagen of prostate cancer cells. Furthermore, overexpression of CCL20 in prostate cancer cells promotes growth and adhesion in vitro and increases tumor growth and invasiveness in the in vivo mouse model [47].

\subsection{Lung Cancer}

Tobacco kills nearly 6 million people each year, and 90\% of the annual 1.59 million lung cancer deaths worldwide are caused by cigarette smoke. CCL20 is significantly upregulated by tobacco carcinogen nicotine-derived nitrosaminoketone [48]. Expression of lncRNA-u50535 is upregulated in lung cancer tissues and cell lines compared with normal tissues and cells, and Western blot and luciferase reporter gene assays have demonstrated that lncRNA-u50535 has also increased the translation and transcription of CCL20 in lung cancer cells [49]. Knockdown of lncRNA-u50535 decreases lung cancer cell proliferation and migration, induces G0/G1 phase arrest, and promotes cell apoptosis with decreased CCL20, CCR6, and phosphorylated ERK (pERK) levels [49]. CCL20/ERK signaling has been further investigated in lung adenocarcinoma samples obtained at surgery and cell lines and assessed for the expression, tissue localization, and production. CCL20 and CCR6 are found to be highly expressed in the majority of samples in the recurrence group (76 and 66\%, respectively), and staining indexes of CCL20 and CCR6 in the recurrence group are 149.3 and 134.4, respectively, which are significantly higher than those in the non-recurrence group (57.2 and 58.0, respectively) [50]. In colony formation assay, ERK signaling and chemokine production have been measured to assess the responsiveness of the A549 cell line to CCL20 stimulation and have found the colony-forming phosphorylation [50]. Collectively, the findings suggest that CCR6 and CCL20 may serve a role in lung adenocarcinoma, leading to proliferation and migration via autocrine or paracrine mechanisms. The disruption of CCL20-CCR6 interactions may be a promising strategy for the treatment of cancer [50]. 


\subsection{Cervical Cancer}

Cervical cancer is the second most common cancer in women worldwide [64]. One study has shown that level of CCL20 in the cervical cancer tissues is significantly higher than that in non-tumor and normal control tissues and strongly positively associates with Th17 cells [51]. CCL20 is also predominantly expressed in the stroma of cervical cancer tissue and correlates with stromal infiltration of CD4+IL17+ cells and with advancing International Federation of Gynecology and Obstetrics (FIGO) stage [52]. Furthermore, cervical cancer cells instruct primary cervical fibroblasts to produce high levels of CCL20 and to attract CD4+IL17+CCR6+ cells [52].

\subsection{Gastric Cancer}

Upregulated CCR6 protein expression has also been observed in the gastric cancer tissues [24]. CT10 regulator of kinase like protein (CrkL) has been identified as a key regulator in EMT, and both CCR6 and CrkL are aberrantly expressed in gastric cancer specimens. The expression of CCR6 and CrkL is also significantly associated with metastasis, stage, and poor prognosis of gastric cancer. The knockdown of CrkL abrogates the CCL20-induced pERK, vimentin, N-cadherin, and MMP2 expression with decreased migration and invasion of gastric cancer cells [53].

\subsection{Ovarian Cancer}

In clinical ovarian cancer samples, high CCR6 expression on ovarian cancer cells positively correlates with cancer metastasis, leading to poor prognosis. Cisplatin-stimulated classically activated macrophages promote ovarian cancer cell migration by increasing CCL20 production, which activates its receptor CCR6 on ovarian cancer cells, triggering EMT. Pharmacological blockage of CCL20 on cisplatin-stimulated activated macrophages and siRNA-mediated inactivation of CCR6 on cancer cells effectively abrogate ovarian cancer cell migration induced by cisplatin-stimulated activated macrophages. These results suggest the CCL20-CCR6 axis as a potential therapeutic target to reduce chemotherapy-induced metastasis in advanced-stage ovarian cancer [54].

\subsection{Renal Cell Carcinoma}

RCC is the most common type of renal cancer, accounting for $3-4 \%$ of adult cancers in the United States [60]. Around $20-40 \%$ of patients with RCC develop recurrence and metastasis after initial surgery and require drug therapy [65]. Moreover, around 70\% of all RCCs have been classified as clear cell RCC (ccRCC) derived from the proximal convoluted tubule [66]. Until the 1990s, immunotherapy, including IFN- $\alpha$ and IL2, had been the only drug therapy for ccRCC, which is immunogenic [67]. Thereafter, vascular endothelial growth factor receptor tyrosine kinase inhibitors had become the main treatment method. In recent years, however, immune checkpoint inhibitors had become the prominent treatment method for RCC, with immune tolerance again becoming the main concern in the treatment of RCC [68].

Several chemokine axes, such as the CCL2-CCR2 axis, the CCL3-CCR5 axis, and the CCL17/22-CCR4 axis, are reported to be involved in ccRCC [69-73]. The CCL20-CCR6 axis is also involved in the growth and progression of RCC. One study has revealed that among patients with RCC, those who have bone metastases have higher serum CCL20 levels than those who do not have bone metastases and that the CCL20-CCR6 axis perhaps be involved in RCC bone metastases [74]. Other studies have found that CCL20 secretion by RCC tissue induces invasion of Treg expressing high levels of CCR6 into RCC tissues, creating an optimal environment for itself $[75,76]$. TAM is an immune cell that greatly influences the TME along with Treg. A recent study has reported an interesting relationship between RCC and TAM via the CCL20-CCR6 axis. In vitro experiments have revealed that macrophage-like cells prepared from human monocytic leukemia cell line THP-1 promote RCC cell migration and that CCL20 substantially contributes to macrophage-induced RCC cell migration. Furthermore, AKT activation is involved in the promotion of RCC migration through the CCL20-CCR6 
axis. Moreover, immunohistochemical staining of human RCC tissues has revealed that high CCR6 expression and macrophage infiltration are poor prognostic factors [55].

\section{The Relationship between the CCL20-CCR6 Axis and Immune Cells}

Immune cell infiltration into tumor tissues has been one of the most important effects of CCL20 on the TME. Specific immune cells recruited into tumor tissues undergo various changes when stimulated by cancer or stromal cells. Such changes favor the survival of cancer cells and promote worse prognosis for many patients. The following subsections have discussed the relationship between the CCL20-CCR6 axis and immune cells.

\subsection{Tumor-Associated Macrophage}

Macrophages, which are mainly responsible for innate immunity along with neutrophils, are the major components of the mononuclear phagocyte system, including myeloid progenitor cells and blood monocytes [77]. Tissue-resident and inflammatory macrophages are derived from bone marrow-derived monocyte progenitor cells circulating in the blood [78]. These progenitor cells extravasate toward target tissues, where they differentiate into mature macrophages and exert various functions depending on the environment. Macrophages can be generally classified into two subsets, M1-type and M2-type macrophages. M1-type macrophages are driven by IFN- $\gamma$, bacterial moieties, such as lipopolysaccharide, and toll-like receptor agonists and function as important cellular components involved in the inflammatory response and antitumor immunity [79]. Conversely, M2-type macrophages are activated by IL4 and IL10 and exert anti-inflammatory and sometimes tumor-promoting effects [79]. Growing evidence has shown that macrophages play a central role in the remodeling of both normal and diseased tissues through angiogenesis, basement membrane destruction, leukocyte infiltration, and immunosuppression. Among them, TAM present in the TME exhibits M2-type macrophage phenotype and is greatly involved in tumor progression. TAM has been shown to secrete angiogenic mediators, such as fibroblast growth factor and thymidine phosphorylase, which promote tumor angiogenesis [80]. They can also sense hypoxia due to vascular deprivation within the tumor and releases vascular endothelial growth factor $\mathrm{A}$, a very potent pro-angiogenic factor, to enhance tumor survival and metastasis [80]. Furthermore, TAM produces MMPs and transforming growth factor- $\beta$ that help with infiltration into tumor cells. Although TAM exerts many functions in cancer progression, reports have shown that chemokines, such as CCL20-CCR6 axis, are strongly involved.

Tumor immunity is deeply involved in the development of melanoma, considering that immune checkpoint inhibitors—nivolumab and ipilimumab—have been shown to be effective [81]. One study has shown that transplanting human melanoma cells into humanized mice and administering human CCL20 every 3 days double tumor growth [82]. High CCL20 expression in the tumor stroma is determined to be a poor prognostic factor, while CCL20 mRNA expression of TAM is higher than that of tumor cells, cancer-associated fibroblasts, $\mathrm{T}$ cells, and peripheral blood monocytes within tumor tissues [82]. CCR6-deficient mice have been found to have reduced incidences of CRC [83]. Moreover, CCL20 plays a role in the progression of CRC by inducing TAM into tumor tissues and promoting TNF $\alpha$ secretion in TAM [83]. Therefore, given that CCR6 deficiency downregulates tumor progression, the CCL20-CCR6 axis could be a therapeutic target [83]. The association between TAM and the CCL20-CCR6 axis has also been reported in pancreatic cancer. One study has shown that co-culturing with M2-type macrophages has enhanced the invasiveness of pancreatic cancer cell lines, whereas transfection with CCR6 RNA interference has significantly reduced the invasiveness of the cell lines [45]. The addition of recombinant CCL20 has enhanced EMT by increasing the expression of p-AKT, p-ERK, and N-cadherin and decreasing the expression of E-cadherin in pancreatic cancer cell lines [45]. TAM infiltration into RCC tissue has also induced EMT through CCR6-AKT pathway activation in RCC cells by secreting CCL20, thereby enhancing the progression of RCC [55]. 


\subsection{Regulatory $T$ Cells}

Tregs are a subset of $\mathrm{T}$ cells that control the autoimmune response and express the endogenous forkhead box protein 33 (Foxp3)+, CD25+, CD4+ phenotype. Dysfunction and aberrant Treg expression have been closely associated with the development of autoimmune diseases. Mutations in the gene encoding the Treg-specific transcription factor Foxp3 inhibit Treg development and cause fatal diseases, such as immune dysregulation, polyendocrine deficiency, and X-linked syndrome [84]. On the contrary, a large number of Tregs infiltrate various cancer tissues and control many cells, such as T cells, B cells, natural killer cells, and DC, which often cause poor clinical prognosis. Furthermore, Tregs regulate various molecules, such as cytotoxic T-lymphocyte-associated antigen-4, IL2, and IL10, and promote tumor tolerance in the TME, making it a potential target for cancer treatment [84].

One study has shown that high CCR6 expression by circulatory Treg and directional migration toward CCL20 promote Treg migration into tumor tissue and that intratumoral CCL20 concentration and tumor-infiltrating Treg number are positively correlated [85]. Moreover, the number of tumor-infiltrating Treg is associated with cirrhosis and tumor differentiation, while the increase in tumor-infiltrating Treg is a poor prognostic factor among patients with HCC. Evidence has shown that Treg is induced by CCL20 and invades tumor tissue, but CCL20 may be derived from tumor cells, macrophages, and other stromal cells [86]. Marked infiltration by CCR6+ Treg has been observed in the CRC tissue, and it is possible that CRC cells and macrophages produce a large amount of CCL20. Injection of recombinant CCL20 into the tumor site has promoted Treg recruitment and tumor progression in CRC-transplanted mice [86]. In vitro experiments on RCC have revealed that renal cancer cell lines barely secrete CCL20, whereas macrophage-like cells markedly secrete the same [55]. Another study has shown that patients with RCC have increased Treg levels in the peripheral blood and tissues, with those having high Treg levels showing poor prognosis [87]. Treg is recruited by not only tumor cells but also TAM-derived CCL20, which may lead to cancer progression and poor prognosis among patients with HCC, CRC, and RCC.

\section{3. $T$ Helper 17 Cells}

Th17 are Th lineage cells defined independently in 2005 from the subsets of Th1 and Th2 [88]. Th17 have been shown to secrete IL17, IL6, IL21, IL22, and TNF- $\alpha$, which play important roles in autoimmune diseases and body defense responses. The primary physiological role of Th17 is to promote host defense against infectious agents and maintain barrier immunity on the skin and mucosal surfaces, such as intestines and lungs [89]. However, Th17 is also involved in inflammatory and autoimmune diseases and plays a detrimental role in psoriasis, rheumatoid arthritis, inflammatory bowel disease, asthma, and systemic lupus erythematosus [90].

Various chemokines, such as CCL2, CCL5, CCL17, CCL20, and CCL22, recruit Th17, depending on the situation [51,91,92]. Moreover, Th17 is often associated with tumors and has been reported in several cancer sites, including the kidney, prostate, colon, breast, hepatocytes, pancreas, and cervix [89]. In fact, reports have shown that Th17 infiltration into tumor tissue is a poor prognostic factor in certain cancers [93-95]. Moreover, one study has shown that CCL20 chemoattracts Th17 in vitro, while Th17, highly expressing CCR6, is significantly accumulated in cervical cancer tissue [51]. The expression level of CCL20 is significantly higher in tumor tissues than in normal control tissues, while CCL20 expression in tissues is positively correlated with Th17 number [51]. Another study has shown that IL6 derived from cervical cancer cells stimulates cervical fibroblasts and induces CCL20 secretion via the CCAAT/enhancer-binding protein $\beta$ pathway [52]. CCL20 attracts CD4+IL17+CCR6+ Th17 and regulates the TME [52]. Therefore, the IL6-CCL20-CCR6 pathway could be a potential therapeutic target [52]. Conversely, Th17 has also been reported to improve the TME. In a large CRC cohort, tumor-infiltrating IL17-producing cells have not worsened clinical outcome and recruit highly cytotoxic CCR5+CCR6+CD8+ T cells via the release of CCL5 and CCL20 [96]. A study, which has evaluated Th1, Th2, Th17, and naive Treg ratios by flow cytometry from 131 patients with RCC and 36 healthy volunteers, has shown that patients with RCC have increased Th2 and Th17 and reduced Th1 cells and 
naive Treg in their peripheral blood [97]. In particular, as the tumor stage and grade progress, Th1 cells and naive Treg in the peripheral blood decrease, whereas Th2 and Th17 increase [97]. Furthermore, the number of tumor-infiltrating Foxp3+ Treg in tumor tissue increases with the progression of tumor stage [97]. This indicates that the balance between Th1 and Th2 cells is biased toward the Th2 profile, whereas the balance between Treg and Th17 is biased toward the Th17 profile in the peripheral blood of patients with RCC [97]. The host's antitumor immunity could also be out of balance with Treg infiltration into the tumor tissue [97]. Thus, Th17 is undoubtedly important in tumor immunology, although its role is complex and bifactorial. As such, further research is needed.

\subsection{Myeloid-Derived Suppressor Cells}

Flow cytometric analysis of MDSC in the peripheral blood and tumor tissues of patients with RCC has shown a positive correlation with tumor grade and stage [98]. Furthermore, CCL2, IL17, and IL18, which are increased in peripheral blood and tumor tissues, may recruit MDSC into tumor tissues [98].

$\mathrm{Gr} 1+\mathrm{CD} 11 \mathrm{~b}+$ cells have long been known to accumulate in the spleen and tumor tissue of mouse tumor models and exert strong immunosuppression [99]. However, these cells, collectively called MDSC in 2007, are heterogeneous and have various phenotypes [100]. MDSC can be broadly classified into granulocytic or polymorphonuclear (PMN-MDSC) and monocytic (M-MDSC). Morphologically, PMN-MDSC resembles neutrophils, while M-MDSC resembles monocytes. While other small subsets, such as immature MDSC (I-MDSC), do exist, most MDSCs are either PMN-MDSC or M-MDSC [101]. The main function of MDSC is immunosuppression, with T cells being their main target. MDSC inhibits tumor immunity through arginase 1 , inducible nitric oxide synthase (iNOS), transforming growth factor- $\beta$, IL10, and cyclooxygenase 2 [101]. PMN-MDSCs are often defined as $\mathrm{CD} 11 \mathrm{~b}+\mathrm{CD} 14-\mathrm{CD} 15+$ cells or CD11b+CD14-CD66b + cells, while M-MDSCs are often defined as CD11b+CD14+HLA-DR-/loCD15-cells [101]. MDSCs are attracted to tumor tissues in response to various cytokines. Accordingly, CCL2 and CCL5 have been observed in M-MDSC, while CXCL1, CXCL5, CXCL6, CXCL8, and CXCL12 have been observed in PMN-MDSC [102]. MDSC suppresses CD8+ T cells, while tumor tissue-induced M-MDSC differentiates into TAM. Hence, tumor tissue is continuously recruited with TAM $[103,104]$.

CCL2, which has been reported in breast cancer, gastric cancer, ovarian cancer, and CRC, is the most representative chemokine that induces MDSC in tumor tissue $[105,106]$. Tumor cell-produced CCL2 induces monocyte infiltration into tumor tissue and differentiates into TAM in the TME [107]. In severe combined immunodeficient (SCID) mice subcutaneously injected with vertebral-cancer of the prostate (VCaP) prostate cancer cell lines, systemic administration of anti-CCL2 neutralizing antibody has significantly slowed tumor growth and significantly suppressed angiogenesis and infiltration of CD68+ macrophages into tumor tissues [107]. Moreover, inhibition of the CCL2-CCR2 axis suppresses MDSC proliferation and migration, as well as TAM invasion, and contributes to TME improvement and patient prognosis. After evaluating MDSC and chemokines in tissues and peripheral blood of 48 RCC patients [108], Najjar et al. showed that the number of PMN-MDSC in tumor tissue was correlated with IL8 and CXCL5. Given that CXCR2 acts as the receptors for both IL8 and CXCL5, the effect of the CXCR2 blockade was examined, while combination therapy comprising anti-programmed cell death 1 (PD1) and CXCR2 blockade was performed on a Renca mouse model [108]. Accordingly, combination therapy caused a reduction in tumor weight and infiltration of CD4+ and CD8+ T cells into the tumor tissue [108]. Although no direct link between CCL20 and MDSC has been observed, MDSC is deeply involved in many tumors. Future studies may find an indirect role through other immune cells and cytokines.

\section{Treatment for Cancers Targeting on the CCL20-CCR6 Axis}

The CCL20-CCR6 axis promotes cancer progression, directly activating cancer cells and indirectly via inactivation of the tumor-immune system, and the blockade of the CCL20-CCR6 axis is thought as 
a promising target. However, clinically available drugs modulating the CCL20-CCR6 axis as anticancer agents are not available so far, and the development of such drugs is absolutely expected.

GSK3050002, a humanized IgG1א antibody with high binding affinity to human CCL20, was administered in a first-in-human study to assess safety, tolerability, pharmacokinetics, immunogenicity, and biological activity. GSK3050002 was well tolerated, and no safety concerns were identified. The pharmacokinetics was linear over the dose range, with a half-life of approximately 2 weeks. The complex of GSK3050002/CCL20 increased in serum and blister fluid with increasing doses of GSK3050002. There were dose-dependent decreases in CCR6+ cell recruitment to skin blisters with maximal effects at doses of $5 \mathrm{mg} / \mathrm{kg}$ and higher, doses at which GSK3050002/CCL20 complex in serum and blister fluid also appeared to reach maximum levels [109].

Both CXCR3 and CCR6 chemokine receptors play crucial roles in the migration of pathological Th1 and Th17 cells during the course of certain inflammatory diseases. A fully humanized IgG-like bispecific antibody, which is simultaneously targeting both CXCR3 and CCR6, has been developed. This bispecific antibody binds to both chemokine receptors and effectively blocks chemotaxis of these cells and induces specific antibody-dependent cell-mediated cytotoxicity in vitro [110].

ASN002 is an oral inhibitor of the Janus kinase/spleen tyrosine kinase signaling pathways, targeting several cytokine axes, including CCL20. ASN002 has been studied as a phase 1B clinical trial in 36 patients with atopic dermatitis. ASN002 has shown strong inhibition of IL-17-mediated CCL20 release in keratinocytes [111].

These drugs targeting the CCL20-CCR6 axis display a potent interventional approach for the treatment of inflammatory and autoimmune diseases; however, the application of these promising drugs for cancer patients may need more basic investigations and clinical trials.

\section{Conclusions and Future Outlook}

Despite CCR6 being the only CCL20 receptor, its role in TME is considerably complex. This is because the cytokine network is intricately involved in and controls tumor progression. Interestingly, CCL20 and CXCL8 have been shown to jointly, but not separately, induce EMT in CRC cells. Moreover, co-expression of CCL20 and CXCL8 is negatively correlated with E-cadherin expression in CRC tissues, confirming two synergistic roles for EMT in CRC cells [112]. CCL2 from RCC tissues may induce TAM [71], secreting CCL20 and inducing Treg and Th17 [55,113]. Th17, in turn, invades RCC tissues and enhances IL8 expression in tumor tissue by releasing IL17 [114]. The IL8-CXCR1 axis activation has been associated with poor prognosis among patients with ccRCC [115]. Thus, cytokines, including chemokines and immune cells, are involved in various networks across many cancers, including RCC (Figure 1). More in vivo experiments and clinical trials are certainly needed to better determine the critical roles of the CCL20-CCR6 axis in cancer development. 


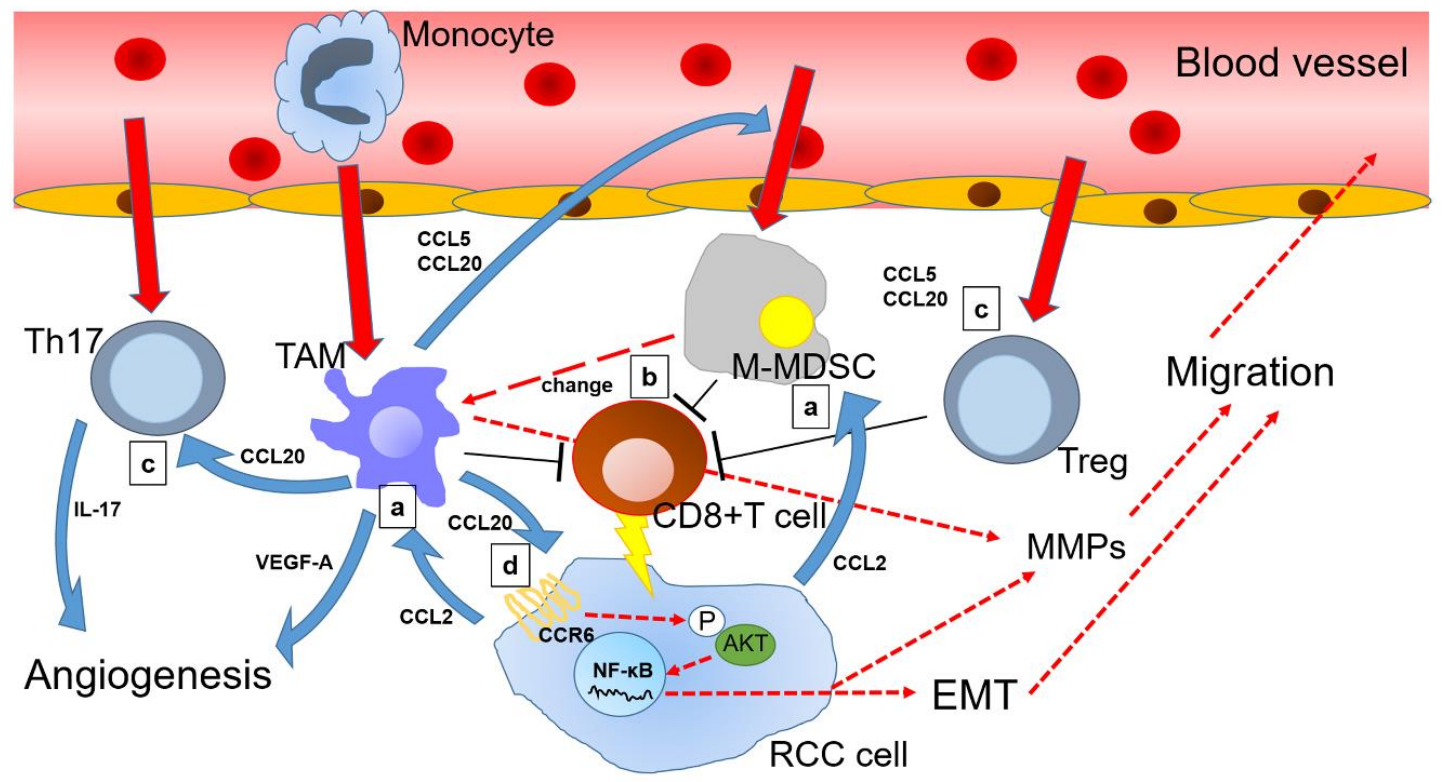

Figure 1. Overview of chemokine (C-C motif) ligand 20 (CCL20) and other related chemokine signals in the renal cell carcinoma microenvironment: (a) Renal cell carcinoma (RCC) cells secrete CCL2 to guide tumor-associated macrophage (TAM) and monocytic myeloid-derived suppressor cells (M-MDSC) toward tumor microenvironment (TME); (b) M-MDSC suppress CD8+ T cells together with TAM, while a portion of M-MDSC changes into TAM, which continues to reside in the TME; (c) TAM mobilizes T helper 17 cells (Th17) and regulatory T cells (Treg) via the CCL20-chemokine receptor 6 (CCR6) axis to enhance angiogenesis and suppress antitumor immunity, thereby indirectly promoting RCC progression; (d) Furthermore, CCL20 binds to CCR6 of RCC cells and induces epithelial-mesenchymal transition (EMT) via AKT activation of RCC cells, thereby directly promoting cancer progression. Solid red arrows indicate cell movement. Dotted red arrows indicate changes in cell status. Blue arrows indicate protein secretion. Long $\mathrm{T}$ shaped bars indicate functional inhibition.

Author Contributions: Conceptualization, K.I.; writing—original draft preparation, S.K.; writing-review and editing, K.I.; supervision, A.M. All authors have read and agreed to the published version of the manuscript.

Funding: This research received no external funding.

Conflicts of Interest: The authors declare no conflict of interest.

\section{Abbreviations}

$\begin{array}{ll}\text { CC } & \text { C-C motif } \\ \text { CCL } & \text { Chemokine (C-C Motif) Ligand } \\ \text { CCR } & \text { C-C Chemokine Receptor } \\ \text { CrkL } & \text { CT10 Regulator of Kinase Like Protein } \\ \text { CRC } & \text { Colorectal Cancer } \\ \text { CXC } & \text { C-X-C Motif } \\ \text { CXCL } & \text { Chemokine (C-X-C Motif) Ligand } \\ \text { CXCR } & \text { C-X-C Chemokine Receptor } \\ \text { DC } & \text { Dendritic Cells } \\ \text { EMT } & \text { Epithelial-Mesenchymal Transition } \\ \text { ER } & \text { Estrogen Receptor } \\ \text { ERK } & \text { Extracellular Signal-Regulated Kinase } \\ \text { Foxp3 } & \text { Forkhead Box Protein P3 } \\ \text { HER2 } & \text { Human Epidermal Growth Factor Receptor 2 } \\ \text { IFN } & \text { Interferon } \\ \text { IL } & \text { Interleukin } \\ \text { IL17A } & \text { Interkeukin-17 A }\end{array}$




$\begin{array}{ll}\text { iNOS } & \text { Inducible Nitric Oxide Synthase } \\ \text { LARC } & \text { Liver and Activation-Regulated Chemokine } \\ \text { MDSC } & \text { Myeloid-Derived Immune Suppressor Cells } \\ \text { MMP } & \text { Matrix Metalloproteinase } \\ \text { NF-kB } & \text { Nuclear Factor-Kappa B } \\ \text { PD1 } & \text { Programmed Cell Death 1 } \\ \text { PR } & \text { Progesterone Receptor } \\ \text { RCC } & \text { Renal Cell Carcinoma } \\ \text { SCID } & \text { Severe Combined Immunodeficient } \\ \text { TAM } & \text { Tumor-Associated Macrophages } \\ \text { Th } & \text { T Helper Cells } \\ \text { TME } & \text { Tumor Microenvironment } \\ \text { TNBC } & \text { Triple-Negative Breast Cancer } \\ \text { TNF } & \text { Tumor Necrosis Factors } \\ \text { TRAIL } & \text { TNF-Related Apoptosis-Inducing Ligand } \\ \text { Treg } & \text { Regulatory T Cells } \\ \text { VCaP } & \text { Vertebral-Cancer of the Prostate }\end{array}$

\section{References}

1. Bell, D.; Chomarat, P.; Broyles, D.; Netto, G.; Harb, G.M.; Lebecque, S.; Valladeau, J.; Davoust, J.; Palucka, K.A.; Banchereau, J. In breast carcinoma tissue, immature dendritic cells reside within the tumor, whereas mature dendritic cells are located in peritumoral areas. J. Exp. Med. 1999, 190, 1417-1426. [CrossRef] [PubMed]

2. Hanahan, D.; Coussens, L.M. Accessories to the crime: Functions of cells recruited to the tumor microenvironment. Cancer Cell 2012, 21, 309-322. [CrossRef] [PubMed]

3. Zlotnik, A.; Yoshie, O. The chemokine superfamily revisited. Immunity 2012, 36, 705-716. [CrossRef]

4. Charo, I.F.; Ransohoff, R.M. The many roles of chemokines and chemokine receptors in inflammation. N. Engl. J. Med. 2006, 354, 610-621. [CrossRef] [PubMed]

5. Griffith, J.W.; Sokol, C.L.; Luster, A.D. Chemokines and chemokine receptors: Positioning cells for host defense and immunity. Annu. Rev. Immunol. 2014, 32, 659-702. [CrossRef] [PubMed]

6. Atreya, R.; Neurath, M.F. Chemokines in inflammatory bowel diseases. Dig. Dis. (Basel Switz.) 2010, 28, 386-394. [CrossRef] [PubMed]

7. Ziegler, M.E.; Hatch, M.M.; Wu, N.; Muawad, S.A.; Hughes, C.C. mTORC2 mediates CXCL12-induced angiogenesis. Angiogenesis 2016, 19, 359-371. [CrossRef]

8. Saito, M.; Sejima, H.; Naito, T.; Ushirogawa, H.; Matsuzaki, T.; Matsuura, E.; Tanaka, Y.; Nakamura, T.; Takashima, H. The CC chemokine ligand (CCL) 1, upregulated by the viral transactivator Tax, can be downregulated by minocycline: Possible implications for long-term treatment of HTLV-1-associated myelopathy/tropical spastic paraparesis. Virol. J. 2017, 14, 234. [CrossRef]

9. Marcuzzi, E.; Angioni, R.; Molon, B.; Cali, B. Chemokines and Chemokine Receptors: Orchestrating Tumor Metastasization. Int. J. Mol. Sci. 2018, 20, 96. [CrossRef]

10. Liu, H.; Yang, Z.; Lu, W.; Chen, Z.; Chen, L.; Han, S.; Wu, X.; Cai, T.; Cai, Y. Chemokines and chemokine receptors: A new strategy for breast cancer therapy. Cancer Med. 2020, 9, 3786-3799. [CrossRef]

11. Sica, A.; Allavena, P.; Mantovani, A. Cancer related inflammation: The macrophage connection. Cancer Lett. 2008, 267, 204-215. [CrossRef]

12. Power, C.A.; Church, D.J.; Meyer, A.; Alouani, S.; Proudfoot, A.E.; Clark-Lewis, I.; Sozzani, S.; Mantovani, A.; Wells, T.N. Cloning and characterization of a specific receptor for the novel CC chemokine MIP-3alpha from lung dendritic cells. J. Exp. Med. 1997, 186, 825-835. [CrossRef] [PubMed]

13. Hromas, R.; Gray, P.W.; Chantry, D.; Godiska, R.; Krathwohl, M.; Fife, K.; Bell, G.I.; Takeda, J.; Aronica, S.; Gordon, M.; et al. Cloning and characterization of exodus, a novel beta-chemokine. Blood 1997, 89, 3315-3322. [PubMed]

14. Xiao, W.; Jia, Z.; Zhang, Q.; Wei, C.; Wang, H.; Wu, Y. Inflammation and oxidative stress, rather than hypoxia, are predominant factors promoting angiogenesis in the initial phases of atherosclerosis. Mol. Med. Rep. 2015, 12, 3315-3322. [CrossRef] [PubMed] 
15. Hieshima, K.; Imai, T.; Opdenakker, G.; Van Damme, J.; Kusuda, J.; Tei, H.; Sasaki, Y.; Takatsuki, K.; Miura, R.; Yoshie, O.; et al. Molecular cloning of a novel human CC chemokine liver and activation-regulated chemokine (LARC) expressed in liver. Chemotactic activity for lymphocytes and gene localization on chromosome 2. J. Biol. Chem. 1997, 272, 5846-5853. [CrossRef] [PubMed]

16. Nandi, B.; Pai, C.; Huang, Q.; Prabhala, R.H.; Munshi, N.C.; Gold, J.S. CCR6, the sole receptor for the chemokine CCL20, promotes spontaneous intestinal tumorigenesis. PLoS ONE 2014, 9, e97566. [CrossRef]

17. Scapini, P.; Laudanna, C.; Pinardi, C.; Allavena, P.; Mantovani, A.; Sozzani, S.; Cassatella, M.A. Neutrophils produce biologically active macrophage inflammatory protein-3alpha (MIP-3alpha)/CCL20 and MIP-3beta/CCL19. Eur. J. Immunol. 2001, 31, 1981-1988. [CrossRef]

18. Yamazaki, T.; Yang, X.O.; Chung, Y.; Fukunaga, A.; Nurieva, R.; Pappu, B.; Martin-Orozco, P.N.; Kang, H.S.; Ma, L.; Panopoulos, A.D.; et al. CCR6 regulates the migration of inflammatory and regulatory T cells. J. Immunol. (Baltim. Md 1950) 2008, 181, 8391-8401. [CrossRef]

19. Baba, M.; Imai, T.; Nishimura, M.; Kakizaki, M.; Takagi, S.; Hieshima, K.; Nomiyama, H.; Yoshie, O. Identification of CCR6, the specific receptor for a novel lymphocyte-directed CC chemokine LARC. J. Biol. Chem. 1997, 272, 14893-14898. [CrossRef]

20. Cook, D.N.; Prosser, D.M.; Forster, R.; Zhang, J.; Kuklin, N.A.; Abbondanzo, S.J.; Niu, X.D.; Chen, S.C.; Manfra, D.J.; Wiekowski, M.T.; et al. CCR6 mediates dendritic cell localization, lymphocyte homeostasis, and immune responses in mucosal tissue. Immunity 2000, 12, 495-503. [CrossRef]

21. Williams, I.R. CCR6 and CCL20: Partners in intestinal immunity and lymphorganogenesis. Ann. N. Y. Acad. Sci. 2006, 1072, 52-61. [CrossRef] [PubMed]

22. Acosta-Rodriguez, E.V.; Rivino, L.; Geginat, J.; Jarrossay, D.; Gattorno, M.; Lanzavecchia, A.; Sallusto, F.; Napolitani, G. Surface phenotype and antigenic specificity of human interleukin 17-producing $\mathrm{T}$ helper memory cells. Nat. Immunol. 2007, 8, 639-646. [CrossRef] [PubMed]

23. Kapur, N.; Mir, H.; Clark Iii, C.E.; Krishnamurti, U.; Beech, D.J.; Lillard, J.W.; Singh, S. CCR6 expression in colon cancer is associated with advanced disease and supports epithelial-to-mesenchymal transition. $\mathrm{Br}$. J. Cancer 2016, 114, 1343-1351. [CrossRef] [PubMed]

24. Zhang, X.G.; Song, B.T.; Liu, F.J.; Sun, D.; Wang, K.X.; Qu, H. CCR6 overexpression predicted advanced biological behaviors and poor prognosis in patients with gastric cancer. Clin. Transl. Oncol. 2016, 18, 700-707. [CrossRef] [PubMed]

25. Annunziato, F.; Cosmi, L.; Santarlasci, V.; Maggi, L.; Liotta, F.; Mazzinghi, B.; Parente, E.; Fili, L.; Ferri, S.; Frosali, F.; et al. Phenotypic and functional features of human Th17 cells. J. Exp. Med. 2007, 204, 1849-1861. [CrossRef]

26. Kondo, T.; Takata, H.; Takiguchi, M. Functional expression of chemokine receptor CCR6 on human effector memory CD8+ T cells. Eur. J. Immunol. 2007, 37, 54-65. [CrossRef]

27. Lee, A.Y.S.; Körner, H. The CCR6-CCL20 axis in humoral immunity and T-B cell immunobiology. Immunobiology 2019, 224, 449-454. [CrossRef]

28. Beatty, G.L.; Gladney, W.L. Immune escape mechanisms as a guide for cancer immunotherapy. Clin. Cancer Res. Off. J. Am. Assoc. Cancer Res. 2015, 21, 687-692. [CrossRef]

29. Binnewies, M.; Roberts, E.W.; Kersten, K.; Chan, V.; Fearon, D.F.; Merad, M.; Coussens, L.M.; Gabrilovich, D.I.; Ostrand-Rosenberg, S.; Hedrick, C.C.; et al. Understanding the tumor immune microenvironment (TIME) for effective therapy. Nat. Med. 2018, 24, 541-550. [CrossRef]

30. McGranahan, N.; Swanton, C. Clonal Heterogeneity and Tumor Evolution: Past, Present, and the Future. Cell 2017, 168, 613-628. [CrossRef]

31. Rucki, A.A.; Foley, K.; Zhang, P.; Xiao, Q.; Kleponis, J.; Wu, A.A.; Sharma, R.; Mo, G.; Liu, A.; Eyk, J.V.; et al. Heterogeneous Stromal Signaling within the Tumor Microenvironment Controls the Metastasis of Pancreatic Cancer. Cancer Res. 2017, 77, 41-52. [CrossRef] [PubMed]

32. Bacigalupo, M.L.; Manzi, M.; Rabinovich, G.A.; Troncoso, M.F. Hierarchical and selective roles of galectins in hepatocarcinogenesis, liver fibrosis and inflammation of hepatocellular carcinoma. World J. Gastroenterol. 2013, 19, 8831-8849. [CrossRef] [PubMed]

33. Krzyszczyk, P.; Acevedo, A.; Davidoff, E.J.; Timmins, L.M.; Marrero-Berrios, I.; Patel, M.; Corina, W.; Lowe, C.; Sherba, J.J.; Hartmanshenn, C.; et al. The growing role of precision and personalized medicine for cancer treatment. Technology 2018, 6, 79-100. [PubMed] 
34. Korkaya, H.; Liu, S.; Wicha, M.S. Breast cancer stem cells, cytokine networks, and the tumor microenvironment. J. Clin. Investig. 2011, 121, 3804-3809. [CrossRef]

35. Nagarsheth, N.; Wicha, M.S.; Zou, W. Chemokines in the cancer microenvironment and their relevance in cancer immunotherapy. Nat. Rev. Immunol. 2017, 17, 559-572. [CrossRef]

36. Ding, X.; Wang, K.; Wang, H.; Zhang, G.; Liu, Y.; Yang, Q.; Chen, W.; Hu, S. High expression of CCL20 is associated with poor prognosis in patients with hepatocellular carcinoma after curative resection. J. Gastrointest. Surg. Off. J. Soc. Surg. Aliment. Tract 2012, 16, 828-836. [CrossRef]

37. Yang, X.; Ran, R.; Du, J.; Qiu, Z.; Cui, L.; Jiang, X.; Wu, M.; Tan, W. CCL20 is overexpressed in hepatocellular carcinoma with bile duct tumor thrombus and correlates negatively with surgical outcome. Int. J. Clin. Exp. Pathol. 2018, 11, 3977-3983.

38. He, H.; Wu, J.; Zang, M.; Wang, W.; Chang, X.; Chen, X.; Wang, R.; Wu, Z.; Wang, L.; Wang, D.; et al. CCR6(+) $B$ lymphocytes responding to tumor cell-derived CCL20 support hepatocellular carcinoma progression via enhancing angiogenesis. Am. J. Cancer Res. 2017, 7, 1151-1163.

39. Tan, H.; Wang, S.; Zhao, L. A tumour-promoting role of Th9 cells in hepatocellular carcinoma through CCL20 and STAT3 pathways. Clin. Exp. Pharmacol. Physiol. 2017, 44, 213-221. [CrossRef]

40. Lee, S.K.; Park, K.K.; Kim, H.J.; Park, J.; Son, S.H.; Kim, K.R.; Chung, W.Y. Human antigen R-regulated CCL20 contributes to osteolytic breast cancer bone metastasis. Sci. Rep. 2017, 7, 9610. [CrossRef]

41. Chen, W.; Qin, Y.; Wang, D.; Zhou, L.; Liu, Y.; Chen, S.; Yin, L.; Xiao, Y.; Yao, X.H.; Yang, X.; et al. CCL20 triggered by chemotherapy hinders the therapeutic efficacy of breast cancer. PLoS Biol. 2018, 16, e2005869. [CrossRef] [PubMed]

42. Wang, D.; Yuan, W.; Wang, Y.; Wu, Q.; Yang, L.; Li, F.; Chen, X.; Zhang, Z.; Yu, W.; Mrimela, N.M.; et al. Serum CCL20 combined with IL-17A as early diagnostic and prognostic biomarkers for human colorectal cancer. J. Transl. Med. 2019, 17, 253. [CrossRef] [PubMed]

43. Wang, D.; Yang, L.; Yu, W.; Wu, Q.; Lian, J.; Li, F.; Liu, S.; Li, A.; He, Z.; Liu, J.; et al. Colorectal cancer cell-derived CCL20 recruits regulatory $\mathrm{T}$ cells to promote chemoresistance via FOXO1/CEBPB/NF-kappaB signaling. J. Immunother. Cancer 2019, 7, 215. [CrossRef] [PubMed]

44. Geismann, C.; Grohmann, F.; Dreher, A.; Hasler, R.; Rosenstiel, P.; Legler, K.; Hauser, C.; Egberts, J.H.; Sipos, B.; Schreiber, S.; et al. Role of CCL20 mediated immune cell recruitment in NF-kappaB mediated TRAIL resistance of pancreatic cancer. Biochim. Et Biophys. Acta Mol. Cell Res. 2017, 1864, 782-796. [CrossRef]

45. Liu, B.; Jia, Y.; Ma, J.; Wu, S.; Jiang, H.; Cao, Y.; Sun, X.; Yin, X.; Yan, S.; Shang, M.; et al. Tumor-associated macrophage-derived CCL20 enhances the growth and metastasis of pancreatic cancer. Acta Biochim. Et Biophys. Sin. 2016, 48, 1067-1074. [CrossRef] [PubMed]

46. Ghadjar, P.; Loddenkemper, C.; Coupland, S.E.; Stroux, A.; Noutsias, M.; Thiel, E.; Christoph, F.; Miller, K.; Scheibenbogen, C.; Keiholz, U. Chemokine receptor CCR6 expression level and aggressiveness of prostate cancer. J. Cancer Res. Clin. Oncol. 2008, 134, 1181-1189. [CrossRef]

47. Beider, K.; Abraham, M.; Begin, M.; Wald, H.; Weiss, I.D.; Wald, O.; Pikarsky, E.; Abramovitch, R.; Zeira, E.; Galun, E.; et al. Interaction between CXCR4 and CCL20 pathways regulates tumor growth. PLoS ONE 2009, 4, e5125. [CrossRef]

48. Wang, G.Z.; Cheng, X.; Li, X.C.; Liu, Y.Q.; Wang, X.Q.; Shi, X.; Wang, Z.Y.; Guo, Y.Q.; Wen, Z.S.; Huang, Y.C.; et al. Tobacco smoke induces production of chemokine CCL20 to promote lung cancer. Cancer Lett. 2015, 363, 60-70. [CrossRef]

49. Wei, W.; Zhao, X.; Zhu, J.; Zhang, L.; Chen, Y.; Zhang, B.; Li, Y.; Wang, M.; Zhang, Z.; Wang, C. IncRNA-u50535 promotes the progression of lung cancer by activating CCL20/ERK signaling. Oncol. Rep. 2019, 42, 1946-1956. [CrossRef]

50. Zhang, X.P.; Hu, Z.J.; Meng, A.H.; Duan, G.C.; Zhao, Q.T.; Yang, J. Role of CCL20/CCR6 and the ERK signaling pathway in lung adenocarcinoma. Oncol. Lett. 2017, 14, 8183-8189. [CrossRef]

51. Yu, Q.; Lou, X.M.; He, Y. Preferential recruitment of Th17 cells to cervical cancer via CCR6-CCL20 pathway. PLoS ONE 2015, 10, e0120855. [CrossRef] [PubMed]

52. Walch-Rückheim, B.; Mavrova, R.; Henning, M.; Vicinus, B.; Kim, Y.J.; Bohle, R.M.; Juhasz-Böss, I.; Solomayer, E.F. Stromal Fibroblasts Induce CCL20 through IL6/C/EBP $\beta$ to Support the Recruitment of Th17 Cells during Cervical Cancer Progression. Cancer Res. 2015, 75, 5248-5259. [CrossRef]

53. Han, G.; Wu, D.; Yang, Y.; Li, Z.; Zhang, J.; Li, C. CrkL meditates CCL20/CCR6-induced EMT in gastric cancer. Cytokine 2015, 76, 163-169. [CrossRef] 
54. Liu, W.; Wang, W.; Wang, X.; Xu, C.; Zhang, N.; Di, W. Cisplatin-stimulated macrophages promote ovarian cancer migration via the CCL20-CCR6 axis. Cancer Lett. 2020, 472, 59-69. [CrossRef] [PubMed]

55. Kadomoto, S.; Izumi, K.; Hiratsuka, K.; Nakano, T.; Naito, R.; Makino, T.; Iwamoto, H.; taegashi, H.; Shigehara, K.; Kadono, Y.; et al. Tumor-Associated Macrophages Induce Migration of Renal Cell Carcinoma Cells via Activation of the CCL20-CCR6 Axis. Cancers 2019, 12, 89. [CrossRef] [PubMed]

56. Ghouri, Y.A.; Mian, I.; Rowe, J.H. Review of hepatocellular carcinoma: Epidemiology, etiology, and carcinogenesis. J. Carcinog. 2017, 16, 1.

57. Poon, D.; Anderson, B.O.; Chen, L.T.; Tanaka, K.; Lau, W.Y.; Van Cutsem, E.; Singh, H.; Chow, W.E.; Ooi, L.L.; Chow, P.; et al. Management of hepatocellular carcinoma in Asia: Consensus statement from the Asian Oncology Summit 2009. Lancet Oncol. 2009, 10, 1111-1118. [CrossRef]

58. Omata, M.; Lesmana, L.A.; Tateishi, R.; Chen, P.J.; Lin, S.M.; Yoshida, H.; Kudo, M.; Lee, J.M.; Choi, B.I.; Poon, R.T.P.; et al. Asian Pacific Association for the Study of the Liver consensus recommendations on hepatocellular carcinoma. Hepatol. Int. 2010, 4, 439-474. [CrossRef]

59. Huang, F.; Geng, X.P. Chemokines and hepatocellular carcinoma. World J. Gastroenterol. 2010, 16, $1832-1836$. [CrossRef]

60. Siegel, R.L.; Miller, K.D.; Jemal, A. Cancer statistics, 2020. CA Cancer J. Clin. 2020, 70, 7-30. [CrossRef]

61. He, X.Y.; Yuan, Y.Z. Advances in pancreatic cancer research: Moving towards early detection. World J. Gastroenterol. 2014, 20, 11241-11248. [CrossRef] [PubMed]

62. Izumi, K.; Chang, C. Targeting inflammatory cytokines-androgen receptor (AR) signaling with ASC-J9(@) to better battle prostate cancer progression. Oncoimmunology 2013, 2, e26853. [CrossRef] [PubMed]

63. Izumi, K.; Fang, L.Y.; Mizokami, A.; Namiki, M.; Li, L.; Lin, W.J.; Chang, C. Targeting the androgen receptor with siRNA promotes prostate cancer metastasis through enhanced macrophage recruitment via CCL2/CCR2-induced STAT3 activation. EMBO Mol. Med. 2013, 5, 1383-1401. [CrossRef] [PubMed]

64. zur Hausen, H. Papillomaviruses and cancer: From basic studies to clinical application. Nat. Rev. Cancer 2002, 2, 342-350. [CrossRef] [PubMed]

65. Molina, A.M.; Motzer, R.J. Current algorithms and prognostic factors in the treatment of metastatic renal cell carcinoma. Clin. Genitourin. Cancer 2008, 6, S7-S13. [CrossRef]

66. Prasad, S.R.; Humphrey, P.A.; Catena, J.R.; Narra, V.R.; Srigley, J.R.; Cortez, A.D.; Dalrymple, N.C.; Chintapalli, K.N. Common and uncommon histologic subtypes of renal cell carcinoma: Imaging spectrum with pathologic correlation. Radiographics 2006, 26, 1795-1806; discussion 1806-1810. [CrossRef]

67. Takezawa, Y.; Izumi, K.; Shimura, Y.; Aerken, M.; Natsagdorji, A.; Iijima, M.; Shigehara, K.; Nohara, T.; Narimoto, K.; Kadono, Y.; et al. Treatment Outcome of Low-dose Interleukin-2 Therapy in Patients with Metastatic Renal Cell Carcinoma. Anticancer Res. 2016, 36, 4961-4964. [CrossRef]

68. Motzer, R.J.; Tannir, N.M.; McDermott, D.F.; Aren Frontera, O.; Melichar, B.; Choueiri, T.K.; Plomack, E.R.; Barthélémy, P.; Porta, C.; George, S.; et al. Nivolumab plus Ipilimumab versus Sunitinib in Advanced Renal-Cell Carcinoma. N. Engl. J. Med. 2018, 378, 1277-1290. [CrossRef]

69. Wang, Z.; Xie, H.; Zhou, L.; Liu, Z.; Fu, H.; Zhu, Y.; Xu, L.; Xu, J. CCL2/CCR2 axis is associated with postoperative survival and recurrence of patients with non-metastatic clear-cell renal cell carcinoma. Oncotarget 2016, 7, 51525-51534. [CrossRef]

70. Schüler, Y.; Lee-Thedieck, C.; Geiger, K.; Kaiser, T.; Ino, Y.; Aicher, W.K.; Klein, G. Osteoblast-secreted factors enhance the expression of dysadherin and CCL2-dependent migration of renal carcinoma cells. Int. J. Cancer 2012, 130, 288-299. [CrossRef]

71. Arakaki, R.; Yamasaki, T.; Kanno, T.; Shibasaki, N.; Sakamoto, H.; Utsunomiya, N.; Sumiyoshi, T.; Tsuruyama, T.; Nakamura, E.; Ogawa, O.; et al. CCL2 as a potential therapeutic target for clear cell renal cell carcinoma. Cancer Med. 2016, 5, 2920-2933. [CrossRef] [PubMed]

72. Wu, Y.; Li, Y.Y.; Matsushima, K.; Baba, T.; Mukaida, N. CCL3-CCR5 axis regulates intratumoral accumulation of leukocytes and fibroblasts and promotes angiogenesis in murine lung metastasis process. J. Immunol. (Baltim. Md: 1950) 2008, 181, 6384-6393. [CrossRef] [PubMed]

73. Berlato, C.; Khan, M.N.; Schioppa, T.; Thompson, R.; Maniati, E.; Montfort, A.; Jangani, M.; Canosa, M.; Kulbe, H.; Hagemann, U.B.; et al. A CCR4 antagonist reverses the tumor-promoting microenvironment of renal cancer. J. Clin. Investig. 2017, 127, 801-813. [CrossRef] [PubMed] 
74. D'Amico, L.; Belisario, D.; Migliardi, G.; Grange, C.; Bussolati, B.; D'Amelio, P.; Perera, T.; Dalmasso, E.; Carbonare, L.D.; Godio, L.; et al. C-met inhibition blocks bone metastasis development induced by renal cancer stem cells. Oncotarget 2016, 7, 45525-45537.

75. Middel, P.; Brauneck, S.; Meyer, W.; Radzun, H.J. Chemokine-mediated distribution of dendritic cell subsets in renal cell carcinoma. BMC Cancer 2010, 10, 578. [CrossRef] [PubMed]

76. Oldham, K.A.; Parsonage, G.; Bhatt, R.I.; Wallace, D.M.; Deshmukh, N.; Chaudhri, S.; Adams, D.H.; Lee, S.P. T lymphocyte recruitment into renal cell carcinoma tissue: A role for chemokine receptors CXCR3, CXCR6, CCR5, and CCR6. Eur. Urol. 2012, 61, 385-394. [CrossRef]

77. Hume, D.A. The mononuclear phagocyte system. Curr. Opin. Immunol. 2006, 18, 49-53. [CrossRef]

78. Davies, L.C.; Jenkins, S.J.; Allen, J.E.; Taylor, P.R. Tissue-resident macrophages. Nat. Immunol. 2013, 14, 986-995. [CrossRef]

79. Italiani, P.; Boraschi, D. From Monocytes to M1/M2 Macrophages: Phenotypical vs. Functional Differentiation. Front. Immunol. 2014, 5, 514. [CrossRef]

80. Chen, P.; Huang, Y.; Bong, R.; Ding, Y.; Song, N.; Wang, X.; Song, X.; Luo, Y. Tumor-associated macrophages promote angiogenesis and melanoma growth via adrenomedullin in a paracrine and autocrine manner. Clin. Cancer Res. Off. J. Am. Assoc. Cancer Res. 2011, 17, 7230-7239. [CrossRef]

81. Hodi, F.S.; Chiarion-Sileni, V.; Gonzalez, R.; Grob, J.J.; Rutkowski, P.; Cowey, C.L.; Lao, C.D.; Schadendorf, D.; Wagstaff, J.; Dummer, R.; et al. Nivolumab plus ipilimumab or nivolumab alone versus ipilimumab alone in advanced melanoma (CheckMate 067): 4-year outcomes of a multicentre, randomised, phase 3 trial. Lancet Oncol. 2018, 19, 1480-1492. [CrossRef]

82. Samaniego, R.; Gutiérrez-González, A.; Gutiérrez-Seijo, A.; Sánchez-Gregorio, S.; García-Giménez, J.; Mercader, E.; Márquez-Rodas, I.; Avilés, J.A.; Relloso, M.; Sánchez-Mateos, P. CCL20 Expression by Tumor-Associated Macrophages Predicts Progression of Human Primary Cutaneous Melanoma. Cancer Immunol. Res. 2018, 6, 267-275. [CrossRef] [PubMed]

83. Nandi, B.; Shapiro, M.; Samur, M.K.; Pai, C.; Frank, N.Y.; Yoon, C.; Prabhala, R.H.; Munshi, N.; Gold, J.S. Stromal CCR6 drives tumor growth in a murine transplantable colon cancer through recruitment of tumor-promoting macrophages. Oncoimmunology 2016, 5, e1189052. [CrossRef] [PubMed]

84. Sakaguchi, S.; Yamaguchi, T.; Nomura, T.; Ono, M. Regulatory T cells and immune tolerance. Cell 2008, 133, 775-787. [CrossRef]

85. Chen, K.J.; Lin, S.Z.; Zhou, L.; Xie, H.Y.; Zhou, W.H.; Taki-Eldin, A.; Zheng, S.S. Selective recruitment of regulatory T cell through CCR6-CCL20 in hepatocellular carcinoma fosters tumor progression and predicts poor prognosis. PLoS ONE 2011, 6, e24671. [CrossRef]

86. Liu, J.; Zhang, N.; Li, Q.; Zhang, W.; Ke, F.; Leng, Q.; Wang, H.; Chen, J.; Wang, H. Tumor-associated macrophages recruit CCR6+ regulatory $\mathrm{T}$ cells and promote the development of colorectal cancer via enhancing CCL20 production in mice. PLoS ONE 2011, 6, e19495. [CrossRef]

87. Griffiths, R.W.; Elkord, E.; Gilham, D.E.; Ramani, V.; Clarke, N.; Stern, P.L.; Hawkins, R.E. Frequency of regulatory $\mathrm{T}$ cells in renal cell carcinoma patients and investigation of correlation with survival. Cancer Immunol. Immunother. CII 2007, 56, 1743-1753. [CrossRef]

88. Harrington, L.E.; Hatton, R.D.; Mangan, P.R.; Turner, H.; Murphy, T.L.; Murphy, K.M.; Weaver, C.T. Interleukin 17-producing CD4+ effector T cells develop via a lineage distinct from the Thelper type 1 and 2 lineages. Nat. Immunol. 2005, 6, 1123-1132. [CrossRef]

89. Zou, W.; Restifo, N.P. T(H)17 cells in tumour immunity and immunotherapy. Nat. Rev. Immunol. 2010, 10, 248-256. [CrossRef]

90. Korn, T.; Bettelli, E.; Oukka, M.; Kuchroo, V.K. IL-17 and Th17 Cells. Annu. Rev. Immunol. 2009, $27,485-517$. [CrossRef]

91. Su, X.; Ye, J.; Hsueh, E.C.; Zhang, Y.; Hoft, D.F.; Peng, G. Tumor microenvironments direct the recruitment and expansion of human Th17 cells. J. Immunol. (Baltim. Md 1950) 2010, 184, 1630-1641. [CrossRef] [PubMed]

92. Chen, D.; Jiang, R.; Mao, C.; Shi, L.; Wang, S.; Yu, L.; Hu, Q.; Dai, D.; Xu, H. Chemokine/chemokine receptor interactions contribute to the accumulation of Th17 cells in patients with esophageal squamous cell carcinoma. Hum. Immunol. 2012, 73, 1068-1072. [CrossRef] [PubMed]

93. Sfanos, K.S.; Bruno, T.C.; Maris, C.H.; Xu, L.; Thoburn, C.J.; DeMarzo, A.M.; Meeker, A.K.; Lsaacs, W.B.; Drake, C.G. Phenotypic analysis of prostate-infiltrating lymphocytes reveals TH17 and Treg skewing. Clin. Cancer Res. Off. J. Am. Assoc. Cancer Res. 2008, 14, 3254-3261. [CrossRef] [PubMed] 
94. Zhang, J.P.; Yan, J.; Xu, J.; Pang, X.H.; Chen, M.S.; Li, L.; Wu, C.; Li, S.P.; Zheng, L. Increased intratumoral IL-17-producing cells correlate with poor survival in hepatocellular carcinoma patients. J. Hepatol. 2009, 50, 980-989. [CrossRef]

95. Tosolini, M.; Kirilovsky, A.; Mlecnik, B.; Fredriksen, T.; Mauger, S.; Bindea, G.; Berger, A.; Bruneval, P.; Fridman, W.F.; Pagès, F.; et al. Clinical impact of different classes of infiltrating T cytotoxic and helper cells (Th1, th2, treg, th17) in patients with colorectal cancer. Cancer Res. 2011, 71, 1263-1271. [CrossRef]

96. Amicarella, F.; Muraro, M.G.; Hirt, C.; Cremonesi, E.; Padovan, E.; Mele, V.; Governa, V.; Han, J.; Huber, X.; Droeser, R.A.; et al. Dual role of tumour-infiltrating T helper 17 cells in human colorectal cancer. Gut 2017, 66, 692-704. [CrossRef]

97. Li, L.; Yang, C.; Zhao, Z.; Xu, B.; Zheng, M.; Zhang, C.; Min, Z.; Guo, J.; Rong, R. Skewed T-helper (Th)1/2and Th17/T regulatory-cell balances in patients with renal cell carcinoma. Mol. Med. Rep. 2015, 11, 947-953. [CrossRef]

98. Guan, X.; Liu, Z.; Zhang, J.; Jin, X. Myeloid-derived suppressor cell accumulation in renal cell carcinoma is correlated with CCL2, IL-17 and IL-18 expression in blood and tumors. Adv. Clin. Exp. Med. Off. Organ Wroc. Med Univ. 2018, 27, 947-953. [CrossRef]

99. Gabrilovich, D.; Ishida, T.; Oyama, T.; Ran, S.; Kravtsov, V.; Nadaf, S.; Carbone, D.P. Vascular endothelial growth factor inhibits the development of dendritic cells and dramatically affects the differentiation of multiple hematopoietic lineages in vivo. Blood 1998, 92, 4150-4166. [CrossRef]

100. Gabrilovich, D.I.; Bronte, V.; Chen, S.H.; Colombo, M.P.; Ochoa, A.; Ostrand-Rosenberg, S.; Schreiber, H. The terminology issue for myeloid-derived suppressor cells. Cancer Res. 2007, 67, 425, author reply 6. [CrossRef]

101. Gabrilovich, D.I. Myeloid-Derived Suppressor Cells. Cancer Immunol. Res. 2017, 5, 3-8. [CrossRef] [PubMed]

102. Kumar, V.; Patel, S.; Tcyganov, E.; Gabrilovich, D.I. The Nature of Myeloid-Derived Suppressor Cells in the Tumor Microenvironment. Trends Immunol. 2016, 37, 208-220. [CrossRef] [PubMed]

103. Corzo, C.A.; Condamine, T.; Lu, L.; Cotter, M.J.; Youn, J.I.; Cheng, P.; Ilcho, H.; Celis, E.; Quiceno, D.G.; Padhya, T.; et al. HIF-1 $\alpha$ regulates function and differentiation of myeloid-derived suppressor cells in the tumor microenvironment. J. Exp. Med. 2010, 207, 2439-2453. [CrossRef] [PubMed]

104. Cortez-Retamozo, V.; Etzrodt, M.; Newton, A.; Rauch, P.J.; Chudnovskiy, A.; Berger, C.; Ryan, R.J.H.; Iwamoto, Y.; Marinelli, B.; Gorbatov, R.; et al. Origins of tumor-associated macrophages and neutrophils. Proc. Natl. Acad. Sci. USA 2012, 109, 2491-2496. [CrossRef] [PubMed]

105. Huang, B.; Lei, Z.; Zhao, J.; Gong, W.; Liu, J.; Chen, Z.; Liu, Y.; Li, D.; Yuam, Y.; Zhang, G.M.; et al. CCL2/CCR2 pathway mediates recruitment of myeloid suppressor cells to cancers. Cancer Lett. 2007, 252, 86-92. [CrossRef]

106. Chun, E.; Lavoie, S.; Michaud, M.; Gallini, C.A.; Kim, J.; Soucy, G.; Odze, R.; Glickman, J.N.; Garrett. CCL2 Promotes Colorectal Carcinogenesis by Enhancing Polymorphonuclear Myeloid-Derived Suppressor Cell Population and Function. Cell Rep. 2015, 12, 244-257. [CrossRef]

107. Loberg, R.D.; Ying, C.; Craig, M.; Yan, L.; Snyder, L.A.; Pienta, K.J. CCL2 as an important mediator of prostate cancer growth in vivo through the regulation of macrophage infiltration. Neoplasia (NY) 2007, 9, 556-562. [CrossRef]

108. Najjar, Y.G.; Rayman, P.; Jia, X.; Pavicic, P.G., Jr.; Rini, B.I.; Tannenbaum, C.; Ko, J.; Haywood, S.; Cohen, P.; Hamilton, T.; et al. Myeloid-Derived Suppressor Cell Subset Accumulation in Renal Cell Carcinoma Parenchyma Is Associated with Intratumoral Expression of IL1 $\beta$, IL8, CXCL5, and Mip-1 $\alpha$. Clin. Cancer Res. Off. J. Am. Assoc. Cancer Res. 2017, 23, 2346-2355. [CrossRef]

109. Bouma, G.; Zamuner, S.; Hicks, K.; Want, A.; Oliveira, J.; Choudhury, A.; Brett, S.; Robertson, D.; Felton, L.; Fernando, D.; et al. CCL20 neutralization by a monoclonal antibody in healthy subjects selectively inhibits recruitment of CCR6(+) cells in an experimental suction blister. Br. J. Clin. Pharmacol. 2017, 83, 1976-1990. [CrossRef]

110. Robert, R.; Juglair, L.; Lim, E.X.; Ang, C.; Wang, C.J.H.; Ebert, G.; Dolezal, O.; Mackay, C.R. A fully humanized IgG-like bispecific antibody for effective dual targeting of CXCR3 and CCR6. PLoS ONE 2017, 12, e0184278. [CrossRef] 
111. Pavel, A.B.; Song, T.; Kim, H.J.; Del Duca, E.; Krueger, J.G.; Dubin, C.; Peng, X.; Xu, H.; Zhang, N.; Estrada, Y.D.; et al. Oral Janus kinase/SYK inhibition (ASN002) suppresses inflammation and improves epidermal barrier markers in patients with atopic dermatitis. J. Allergy Clin. Immunol. 2019, 144, 1011-1024. [CrossRef] [PubMed]

112. Cheng, X.S.; Li, Y.F.; Tan, J.; Sun, B.; Xiao, Y.C.; Fang, X.B.; Zhang, X.F.; Li, Q.; Domg, J.H.; Li, M.; et al. CCL20 and CXCL8 synergize to promote progression and poor survival outcome in patients with colorectal cancer by collaborative induction of the epithelial-mesenchymal transition. Cancer Lett. 2014, 348, 77-87. [CrossRef] [PubMed]

113. Kaneko, S.; Kondo, Y.; Yokosawa, M.; Furuyama, K.; Segawa, S.; Tsuboi, H.; Kanamori, A.; Matsumoto, I.; Yamazaki, M.; Sumida, T. The ROR $\gamma \mathrm{t}-\mathrm{CCR} 6-C C L 20$ axis augments Th17 cells invasion into the synovia of rheumatoid arthritis patients. Mod. Rheumatol. 2018, 28, 814-825. [CrossRef]

114. Inozume, T.; Hanada, K.; Wang, Q.J.; Yang, J.C. IL-17 secreted by tumor reactive T cells induces IL-8 release by human renal cancer cells. J. Immunother. (Hagerstown Md 1997) 2009, 32, 109-117. [CrossRef] [PubMed]

115. Corrò, C.; Healy, M.E.; Engler, S.; Bodenmiller, B.; Li, Z.; Schraml, P.; Weber, A.; Frew, I.J.; Rechsteiner, M.; Moch, H. IL-8 and CXCR1 expression is associated with cancer stem cell-like properties of clear cell renal cancer. J. Pathol. 2019, 248, 377-389. [CrossRef]

(C) 2020 by the authors. Licensee MDPI, Basel, Switzerland. This article is an open access article distributed under the terms and conditions of the Creative Commons Attribution (CC BY) license (http://creativecommons.org/licenses/by/4.0/). 